\title{
US biologist accused of robbing colleagues
}

Geoff Brumfiel, Washington

A biologist at the Dana-Farber Cancer Institute in Boston has been accused of swindling friends and colleagues out of more than half-a-million dollars to support a non-existent start-up company in China.

But the researcher, 38-year-old Weidong $\mathrm{Xu}$, says that he raised the money honestly to support the study of severe acute respiratory syndrome (SARS) - only to lose it in a Nigerian investment scam.

$\mathrm{Xu}$ pleaded not guilty to stealing $\$ 160,000$ from six colleagues between July and September 2003, in a hearing at Roxbury District Court in Boston on 31 March. Prosecutors allege that he also took $\$ 450,000$ from almost 30 others.

Arnold Abelow, Xu's lawyer, says that his client fell prey to a Nigerian investment scam that promised to return $\$ 50$ million on an investment of $\$ 600,000$. He says that $\mathrm{Xu}$ always intended to fund a SARS-research company in his native China, but thought that the project could have a greater impact with the extra money. "He saw a fax in the Dana-Farber office from some people in Nigeria, and he fell for it,"Abelow says.

In a statement, the Dana-Farber Institute said that its officials notified the police as

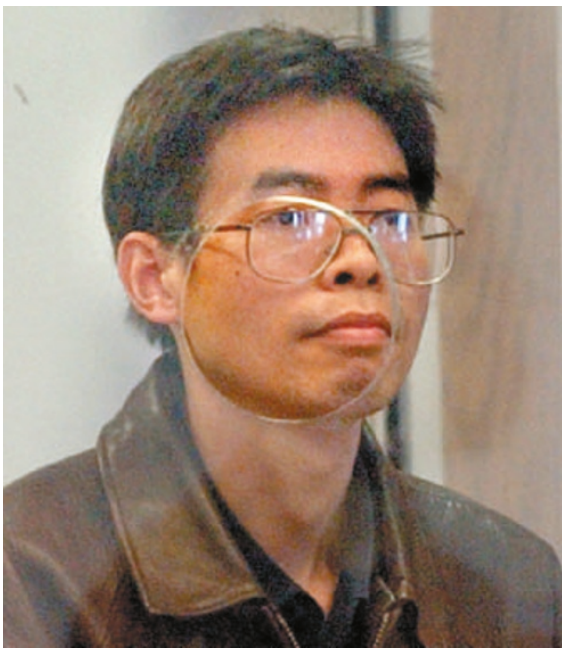

In the dock: Weidong Xu claims he lost funds for SARS research in a Nigerian investment scam.

soon as they were aware of the issue. When the police arrived to interview $\mathrm{Xu}$, the court was told, they found him at a cafeteria arguing with another employee, who said he had given Xu more than $\$ 5,000$. Xu was immediately arrested; he is being held at the Suffolk County Jail in Boston, pending a court hearing on 23 April.
Until last month - when the institute fired him for reasons that it has not disclosed, but says are unrelated to the criminal charges - Xu had spent a low-key but respectable career in AIDS research. He had been at the Dana-Farber Cancer Institute since 1999, when virologist Ruth Ruprecht hired him to look for antibodies that might lead to HIV vaccines.

In 1993, after receiving a master's degree from Beijing Agricultural University, Xu went to Washington State University in Pullman to pursue a doctorate in biochemistry. On completing it in 1997, he joined the laboratory of Flossie Wong-Staal, a prominent AIDS researcher at the University of California, San Diego. "He was good at the bench, especially at molecular techniques," says Wong-Staal, now chief scientist at San Diego-based biotechnology company Immusol.

As a young biologist, $\mathrm{Xu}$ had a keen interest in business, says Thipparthi Reddy, a microbiologist who worked alongside Xu in San Diego and co-authored papers with him. "He was a patents-oriented kind of guy, and he always used to say: 'I want to work for a company', says Reddy, now at Wayne State University, Detroit.

\section{California edges towards farming drug-producing rice}

\section{Rex Dalton, San Diego}

Plans to step up cultivation of rice that is genetically modified to yield pharmaceuticals are sparking fierce opposition from some environmental scientists and farmers in California.

On 29 March, the California Rice Commission decided by 6 votes to 5 to advise the state's food and agriculture department to let Ventria Bioscience of Sacramento grow about 50 hectares of the rice at sites near San Diego. The department is expected to make a final decision later this month - approval would mean the rice could be planted immediately for harvest in the autumn.

Ventria wants to grow two types of rice, one modified to produce the human protein lactoferrin, which can be used to treat anaemia, and the other yielding lysozyme, an antimicrobial that is used to fight diarrhoea. In each case, it plans to grow about 60 tonnes of rice that would be processed to make $600 \mathrm{~kg}$ of the protein.

The sites have been chosen because of their remoteness from commercial rice farms in northern California. But some farmers claim that the rice, which isn't meant for human or animal consumption,

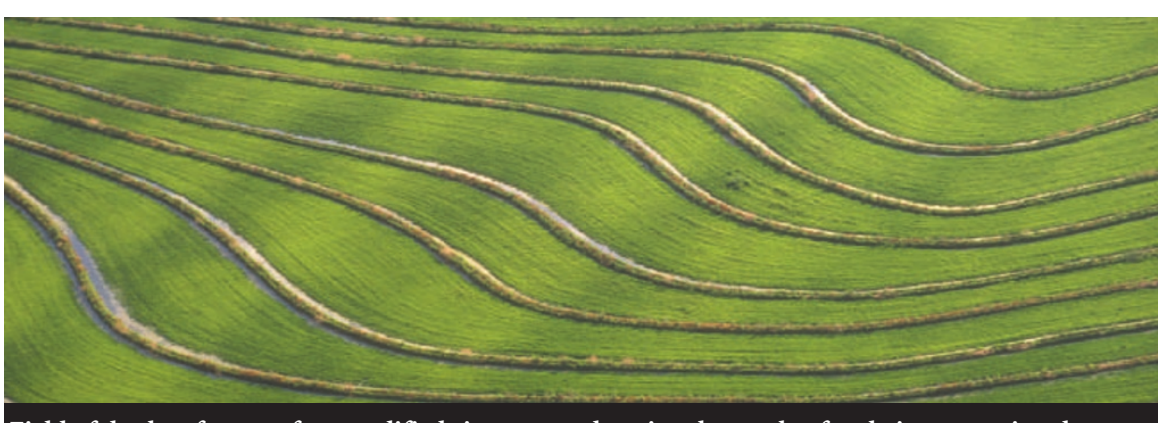

Field of doubts: farmers fear modified rice may undermine the market for their conventional crops.

could still cross-pollinate with food crops via migratory birds or through the water supply. Critics also say that perceptions of such a risk could damage California's rice exports to Japan and Europe, which were worth about $\$ 500$ million last year.

"We are opposed to the use of food crops as platforms to produce chemicals," says Bryce Lundberg of Lundberg Family Farms in Richvale, which grows about 1,400 hectares of rice, some of it by organic methods.

Prospects of growing crops in the United States with transgenes added to produce drugs have suffered several setbacks, including a possible case of contamination of soya beans and maize in Iowa in 2002 , which resulted in a $\$ 250,000$ fine for the Texas-based producer, ProdiGene.

Ventria's crop has been billed as the first of its type in California - although the company has already been growing the rice experimentally in the state for about five years. It also has experimental plots in Hawaii.

The company's chief executive, Scott Deeter, says that the firm grew 16 hectares of the rice last year at undisclosed locations in California. The US Department of Agriculture permitted these experiments, on condition the rice be grown at least 30 metres from conventional rice. 